\title{
Ethical Climate and Organizational Citizenship Behaviors: the Mediating Role of Organizational trust
}

\author{
Meryem EL ALAOUI AMINE * \\ Faculty of Juridical, Economic and Social Sciences- Salé, \\ Mohammed V University, Rabat \\ Avenue des Nations Unies B.P:8007, Agdal, Rabat, Morocco.
}

\begin{abstract}
In this paper, we study the effects of ethical climate on Organizational Citizenship Behaviors (OCB) and the mediation role of organizational trust. The empirical verification of the conceptual model was conducted through a survey of 283 employees in telecommunication services in Morocco. The structural equation modeling approach was used to test the proposed hypotheses. The main results of this paper indicate the existence of a positive and significant relationship between ethical climate and OCB. Also, organizational trust fully mediates the relationship between ethical climate and OCB. Research results were discussed and managerial implications were outlined.
\end{abstract}

Keywords: Ethical climate, Organizational Citizenship Behaviors (OCB), Organizational Trust.

DOI: $10.7176 / \mathrm{EJBM} / 12-3-05$

Publication date: January $31^{\text {st }} 2020$

\section{1- Introduction}

In recent years, the financial and ethical scandals of multinational companies such as Enron, Worldcom, Arthur Andersen, Xerox ... had a negative impact on the global economy. The integration of ethical values within companies has become a necessity to ensure the survival of business. At the intra-organizational level, the quality of relationships at all levels of relationships (e.g., leader-member exchange, coworker exchange, and team-member exchange) could be characterized by mutual respect, trust, and obligation between the parties involved (Uhl-Bien, Graen, and Scandura ,2000,Ong, 2013). The creation of an ethical climate is reflected in the development of an attractive working environment for competent and motivated employees, given the working conditions and means put in place by the company. It also expresses the willingness of managers to guide or control employees' attitudes and behaviors (Pariente et al., 2010) in order to improve their productivity and performance.

Employees Job performance depends not only on the tasks assigned but also on employees behaviors and attitudes generally named Organizational Citizenship Behaviors (OCB) (Borman and Motowildo 1993, Johnson et al., 2009 ; Dalal et al., 2009 ; Rich et al., 2010 ). These behaviors are important in the service sector where employee involvement is one of the characteristics of a service delivery (lovelock et al. , 2008)

In this context fits our research, our goal is to study the effects of ethical climate on OCBs through the mediation of organizational trust by taking the case of employees in telecommunication services in Morocco. This paper is structured as follows: In the first place, and based on a literature review, we will try to establish the conceptual model and to develop the research hypotheses. In second place, we will present the research methodology and measuring instruments. Third, we will expose the empirical results of the Principal Component Analysis (PCA), Structural Equation Modeling and mediation test. Finally, we will try to discuss the results and highlight the managerial implications.

\section{2- Literature review and hypothesis development}

2.1 Ethical climate

Various scholars have studied and defined Ethical climate in management literature. As early as the 1970s, ethical climate was defined as "a stable, psychological meaningful, shared perception employees hold concerning ethical procedures and policies existing in their organization" Schneider (1975:474). Victor and Cullen $(1987,1988)$ introduced the ethical climate framework according to which "ethical climate refers to shared perceptions between members of an organization or part of an organization as to "what constitutes right behavior" and arises when "members believe that certain forms of ethical reasoning or behavior are expected standards or norms for decision making within the firm" (Martin \& Cullen, 2006: 177). Other definitions proposed by Mayer et al. (2010), Huang, et al. (2012) and Hwang and Park (2014) have focused on the collective aspect of the ethical climate. Their definitions underline the importance of shared perceptions of employees, but also how ethical issues are generally (and should be) addressed within an organizational context and what is considered to be ethically correct behavior (Grobler ,2015).

Ethical climate is created and developed, within an organization, on the basis of policies, practices, and procedures that an organization rewards, supports, and expects with regard to ethics. As such, ethical climates provide valuable guidance to employees by reinforcing the normative systems that guide ethical decision making and behavior (Victor and Cullen 1988, Arnaud and Schminke, 2012, Newman et al. 2017). Ethical climate 
therefore influences both the decision making and subsequent behavior in response to ethical dilemmas (Grobler ,2015).

Martin and Cullen, (2006) indicated that the ethical climate serves as a map that generates ideas and decisions within the organization and determines the direction in which it will move as it is put into practice (Çavuş and Develi , 2017) .Singhapakdi et Vitell (2007) have indicated that the institutionalization of ethics is vital in employees perception of ethics, which in turn can lead to more ethical behavior. The authors define the institutionalization of ethics as « the degree to which an organization explicitly and implicitly incorporates ethics into its decision-making processes » (Singhapakdi \& Vitell ,2007, p:284). The implicit integration of ethics means that ethical behaviors are implied or are not expressed directly. They appear mainly in organizational culture, ethics of leaders and communication ( Jose \& Thibodeaux ,1999). The explicit integration of ethics means ethical behaviors are formally expressed. The explicit forms include codes of ethics, ethics training, newsletters and ethical charters (Jose \& Thibodeaux, 1999). In this context Singhapakdi and Vitell (2007) emphasized that explicit institutionalization of ethics has a significant impact on the perception of the importance of ethics by employees. However, companies must maintain explicit rules and guidelines in order to ensure compliance and enforcing codes of conduct to clarify to employees the appropriate actions to achieve.

Employee perception is influenced by several factors such as the content and specificity of ethical codes, how it was communicated to employees as well as the effectiveness of the system of rewards / punishment for noncompliance or consistency to the instructions of the code of ethics (Schwartz, 2001). Stevens (2008) argues that ethical codes can be an effective instrument for the formation of ethical behaviors of employees and a decisionmaking guide. He said that the culture and communication are the keys of codes success. Moreover, employees should be aware of code content and even participate in its development in order to reach a consensus of opinion between the employee and the organization. Sharing values reflects, not only the recognition of employee importance, but also organizational culture.

\subsection{Organizational Citizenship Behaviors $(O C B)$.}

Organizational Citizenship Behaviors (OCB) was defined initially by Organ and Bateman (1983) as "behaviors of an individual who is left to his free choice, not directly or explicitly recognized by the formal reward system and, as a whole, promotes the effective functioning of the organization" (Organ, 1988, P:4). However, after the introduction of this concept by Organ different experts have clarified this issue using concepts such as Extra-role Behavior, Prosocial Organizational Behavior, Organizational Spontaneity and Contextual Performance (VanDyne et al., 1995, Farzianpour et al. 2011).

An overview of the literature concerning OCB, shows the lack of consensus about the dimensions of this concept. In fact, behavioral content of OCB is multidimensional. According to Organ $(1988,1990)$ and Organ et al., (2006), it is composed of five elements : 1/ altruism (the behavior directly turned to the help of a specific person, in situations of face-to-face); 2 / being conscientious (impersonal behaviors in accordance with the rules of the company (be punctual ....) ; 3/ sportiness (does not complain about trivial things) ; 4/ courtesy (failure to consult the other before performing actions); 5 / civic virtue (the act of worrying about issues of concern to the organization).

Williams \& Anderson (1991) have gathered the five components of the OCB in two broad categories of behaviors depending on the beneficiary: These are OCBs oriented to the individual (OCBI) and the OCBs oriented to the organization (OCBO). The OCBI categories are behaviors that immediately benefit specific individuals and indirectly contribute to the organization effectiveness (Williams and Anderson, 1991, Mohammad et al., 2010). OCBI composed of behaviors that exhibit intentions to assist others such as altruism, maintaining the peace, and cheerleading behaviors. other authors (Farh, Earley, and Lin, 1997, Harper, 2015) include also in this category interpersonal helping and coworker's harmony. The OCBO is defined by Williams and Anderson (1991) as behaviors that benefit the organization in general and adhere to organizational rules and policies and volunteer to committees. whereas Podsakoff et al. (2000) defined OCBO as the organizational compliance which involve the internalization of the organization rules and policies. This category includes conscientiousness, civic virtue and sportsmanship, organizational allegiance, endorsement and commitment to the organization's objectives, job dedication, taking charge and promoting the company.

\subsection{Organizational trust}

Trust is "a phenomenon of reduction of uncertainty, but which married by an individual's vulnerability of individuals trusting. It is also a dynamics variable and which changes, in time and space, by continuous adjustments relating to information collected by the parties committed in the relationship "(Khlif, 2000: 3). Beside the concept of commitment, trust is considered by Morgan and Hunt (1994) as the most important mediating variable in the exchange relationship. It works as a control mechanism reducing opportunist behaviors in contexts of exchanges characterized by uncertainty and the dependence. Organizational trust focuses on the role of trust in the development of a sustainable employment relationship (Dirks and Ferrin, 2002). In fact, empirical studies show, 
in general, that trust is directly related to the quality of the employment relationship that results, measured through a set of attitudes, including the commitment to their organization and intention to leave the company (Dirks et Ferrin, 2002). However, it is possible to distinguish several types of trust according to the chosen reference that may have a particular effect on the quality of the employment relationship. "Employees can develop a trusting relationship towards at least two references, including the supervisor and general representatives of the organization" Whitener (1998: 393). The trust of employee to his organization is more related to attitudes-oriented organization and not the daily work such as organizational commitment and intention to leave the company (Wat and Shaffer, 2005).

\section{3- Conceptuel Framework}

\section{3-1. Ethical climate and Organizational Citizenship Behaviors}

Based on an empirical study, Çavuş and Develi (2017) demonstrated that there is a positive and direct relationship between ethical climate and OCBs. More precisely, ethical climate has significant and positive relationship between sportsmanship, civic virtue and courtesy but, it has not significant relationship between altruism and conscientiousness which are dimensions of OCB.

Also, Lee and Ha-Brookshire (2018) studied with U.S. fashion retail employees the effects of ethical climate on OCB. They found that the ethical climate of an organization positively affects employees' OCB, consistent with previous studies in non-fashion retail organizations. the authors added that the role of employees on the organization's overall sustainability performance was found to be highly important. therefore, the authors have recommended the establishment of the ethical climate within the organization to enhance sustainability through employees' OCB.

Other empirical studies have shown that the ethical climate indirectly influences OCBs through other mediation and moderation variables. This is the case, for example, of Pagliaro et al. (2018) who evaluated the impact of two types of ethical climate namely: ethical organizational climate of self-interest, and an ethical organizational climate of friendship on Organizational Citizenship Behaviors (OCBs), and Counterproductive Work Behaviors (CWBs). The results of their research indicate that the two ethical climates were independently related to organizational identification and moral disengagement. These, in turn, mediated the effects of ethical climates on OCBs and CWBs. likewise, the work of Shin Y. (2012) who showed that the relationship between ethical climate and firm-level collective OCB was moderated by climate strength.

To this end we put the following hypothesis:

Hypothesis 1: The ethical climate has a positive and direct effect on Organizational Citizenship Behaviors (OCB).

\section{3-2. Ethical climate and organizational trust}

According to Pučètaite and Lämsä (2008a), it is possible to build organizational trust through ethical management tools such as ethics codes, ethics training, auditing, ethics... The authors postulated that the promotion of organizational trust is a process that involves organizational practices based on ethical principles. Because ethics management tools designed to manage organizational values, principles, and standards of behavior in an organization, these tools can enhance the use of ethical business practices and therefore the development of organizational trust.

Pučètaitė R., Lämsä A.M., (2008 b) suggested that ethics in the workplace and organizational trust are not static phenomena but rather dynamic. This can be explained by the fact that attitudes, behavioral norms and principles that constitute the ethics in the workplace may change due to external environmental pressures (eg, expectations for product quality) or the pressure of the internal environment (eg training programs aimed at improving employee skills).

for this purpose, we suggest the following hypothesis:

Hypothesis 2: The ethical climate has a positive and significative effect on Organizational trust .

\section{3-3 Organizational trust and Organizational Citizenship Behaviors}

Research's has shown that organizational trust has a positive effect on OCB (Dirks and Ferrin ,2002, Ong, 2013; Singh and Srivastava, 2009, 2016). Trust plays an important role in social exchange among organizational members (Rubin, Bommer and Bachrach, 2010) and influences employees' behaviors towards others. In the same way, the OCB is grounded in social exchange theory, which states that individuals sharing trusting relationships try to reciprocate with extra-role behaviors (Singh and Srivastava, 2016). Organ (1988) indicates that OCB promotes employee reciprocation. In fact, "Organizational trust is influenced by a company's overall policies and procedures. Employees sharing a trusting relationship with their organization reciprocate OCB directed towards both an individual and the organization contributing to the smooth functioning of the organization" (Singh and Srivastava, 2016, p: 603).

Hypothesis 3: Organizational trust has a positive and significative effect on Organizational Citizenship 


\section{Behaviors $(\mathrm{OCB})$.}

Since the ethical climate influences organizational trust and this latter influence OCB, we can assume that there is an indirect relationship between ethical climate and $\mathrm{OCB}$ and that organizational trust can play the role of mediator between the two variables.

For this purpose, we suggest the following hypothesis:

Hypothesis 4: Ethical Climate has a positive and significant effect and Organizational Citizenship Behaviors through Organizational trust

Hypothesis 5: Organizational trust mediates the relationship between ethical climate and OCB

Our conceptual model is presented in figure 1 .

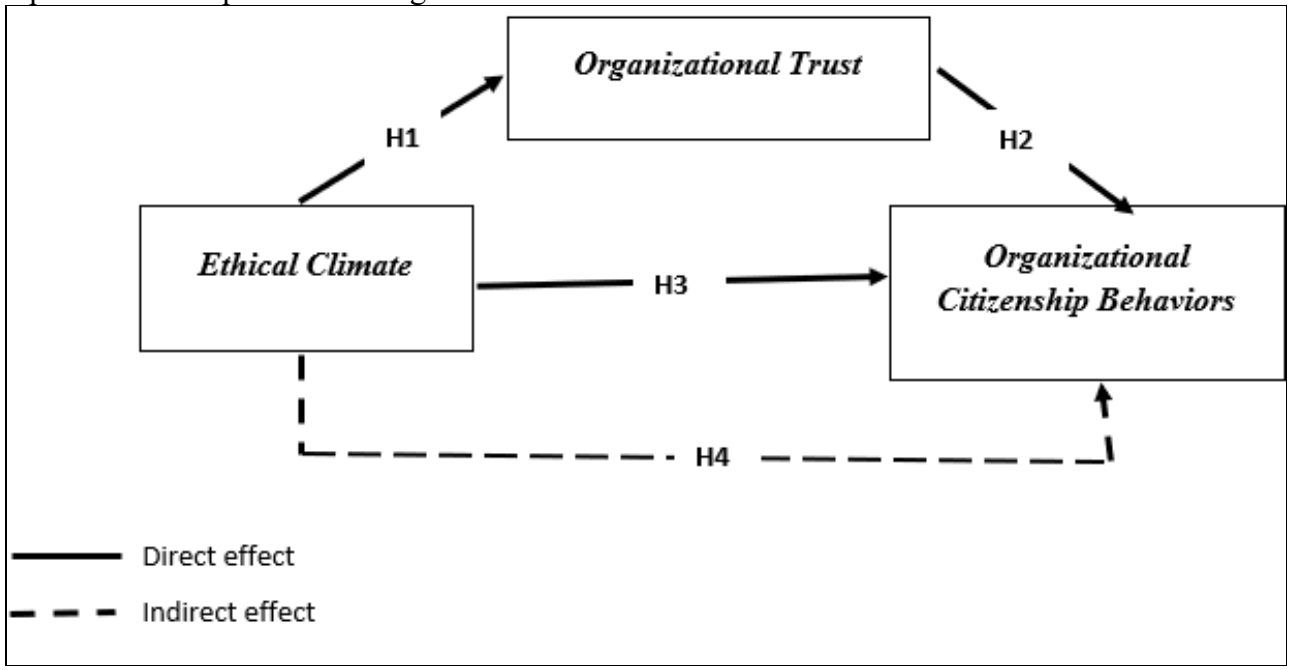

Figure 1. Our conceptual model linking the ethical climate to OCB through organizational trust

\section{4- Methodology and measurement}

4-1 Data collection and sample

The hypotheses were examined by collecting data from employees at telecommunication services in Morocco. A questionnaire was administered directly to employees with the aim to increase the reliability of the study and response rates. We adopted the method of convenience for the selection of our sample. 380 questionnaires were distributed among employees. 298 employees agreed to answer our questions which represent a response rate of $78.42 \%$. However, 15 questionnaires were not completed correctly or contained missing data. These were removed from the study. Finally, there are 283 valid questionnaires.

\section{4-2 Data analysis}

In order to analyze our data, we used Principal Component Analysis (PCA) and Structural Equation Modeling (SEM). The PCA was performed through (SPSS. 17), to reduce the number of items. SEM has been achieved through the AMOS 18.0 software. They were performed in two steps as recommended by Hair, (2010) and Kline, (2011). The first step, is to study the measurement model that describes how latent variables are measured. Validation of the measurement model is achieved by Confirmatory Factor Analysis (CFA). A second step, is to analysis structural model that describes the relationships between latent variables. Assessing the fit of the model was carried out on the basis of the most commonly used fit indices such as: Chi2, CMIN/DL, GFI (Goodness of fit index), CFI(Comparative Fit Index) et RMSEA (Root Mean Squared Error of Approximation)).

Mediation tests have been made according to the approach of Baron and Kenny (1986). According to these authors, the following four steps must be verified : (1) independent variable (IV) predicts dependent variable (DV) (path-c), (2) IV must predicts mediating variable (MV) (path-a), (3) MV must be related to DV (path-b), and (4) when both IV and MV are included, IV no longer predicts DV (full mediation) or lessened predicting DV (partial mediation) (path-c').

\section{4-3 Measurement of the constructs}

In this research, valid instruments of other works were used and adaptations related to the context of the study and to the sector of activity. We adopted for each item a five-point Likert scale ranging from "1: Not at all agree" to "5: strongly agree." The measurements of the constructs in this study are explained in the following.

- Ethical Climate: reference was made to the scale proposed by Schwepker et al (1997) consisting of 6 items. This scale used to assess the presence and the application of the codes of ethics and deontology and the actions 
of managers concerning ethics and business ethics policies. The Principal Component Analysis (PCA) was performed. However, two items cross-loading and were removed from our study (Hair et al ,2010). Alpha cronbach value is 0.769 .

- Organizational Trust: The organizational trust is a major component of social exchange that is built in a sustainable and reciprocal exchange process. We opted for the scale proposed by Robinson and Rousseau (1994) consisting of 7 items, which apprehends trust with general and cognitive manner. However, the result of PCA indicated that two items cross-loading and were removed from our study (Hair et al, 2010). Alpha cronbach value is 0.872 .

- Organizational Citizenship Behavior (OCB): The literature distinguishes between two dimensions of OCB (Williams \& Anderson, 1991; Mohammad el al 2011): OCBs at the individual level (OCBi) and OCBs at the organization level (OCBo). In our research we opted for the measure of the scale proposed by Lee \& Allen (2002) containing the items of OCBs at the organization level consisting of 7 items. Nevertheless, following the PCA three items cross-loading and were removed from our model. Alpha cronbach value is 0.824 .

\section{5- Empirical result}

5-1 Measurement Model

Confirmatory Factor Analysis (CFA) was used to test the measurement model. The method used is Maximum Likelihood on AMOS 18. The measurement model estimate shows an adequate fit to the index adjustments. In fact, $\mathrm{CMIN}=225,526, \mathrm{df}=60, \mathrm{CMIN} / \mathrm{DL}=3,759$ less than 5 recommended by Hair et al. (2010). Also, GFI=0,905 and $\mathrm{CFI}=0,92$ above 0.9 recommended by Hair et al. (2010) and Kline (2011). RMSEA $=0.095$ which less than 0.1 indicated by Akrout, (2010) and Kline, (2011).

The measurement model has a good reliability and satisfied convergent validity and discriminant validity (see table 1). Convergent validity occurs when (a) all factor loading are significantly over 0.50 threshold (Fornell and Larcker,1981); (b) Average Variance Extracted (AVE) in items by their respective constructs is greater than the variance unexplained (AVE $\geq 0.50$ ) (Fornell and Larcker, 1981); and (c) factor composite reliability is equal to or greater than 0.60 (Fornell and Larcker, 1981). Discriminant validity is achieved when Maximum Shared Variance (MSV) and the Average Shared Squared Variance (ASV) were both lower than the Average Variance Extracted (AVE) for all the constructs (Hair et al., 2010).

Table 1. Convergent and discriminant validity

\begin{tabular}{|c|c|c|c|c|c|c|c|}
\hline FACTEURS & $\begin{array}{c}\text { factor } \\
\text { loading }\end{array}$ & CR & AVE & MSV & ASV & $\begin{array}{c}\text { convergent } \\
\text { validity }\end{array}$ & $\begin{array}{c}\text { discriminant } \\
\text { validity } \\
\end{array}$ \\
\hline Reference value & & $\begin{array}{l}>0,6 \\
\text { ou } 0,7\end{array}$ & $>0,5$ & & & $\begin{array}{c}C R>A V E \text { and } \\
\text { AVE }>0,5\end{array}$ & $\begin{array}{l}\text { MSV <AVE } \\
\text { ASV <AVE }\end{array}$ \\
\hline $\begin{array}{c}\text { Ethical Climate } \\
\text { EC1 } \\
\text { EC2 } \\
\text { EC3 } \\
\text { EC4 }\end{array}$ & $\begin{array}{c}0.663 \\
0.927 \\
0.66 \\
0.532\end{array}$ & 0.796 & 0,504 & 0,033 & 0,029 & Yes & Yes \\
\hline $\begin{array}{c}\text { Organizational Trust } \\
\text { OT1 } \\
\text { OT2 } \\
\text { OT3 } \\
\text { OT4 } \\
\end{array}$ & $\begin{array}{l}0.645 \\
0.736 \\
0.902 \\
0.778 \\
\end{array}$ & 0,878 & 0,594 & 0,426 & 0,226 & Yes & Yes \\
\hline $\begin{array}{c}\text { Organizational } \\
\text { Citizenship Behaviors } \\
\text { OCB1 } \\
\text { OCB2 } \\
\text { OCB3 } \\
\text { OCB4 } \\
\end{array}$ & $\begin{array}{l}0.654 \\
0.724 \\
0.973 \\
0.591 \\
\end{array}$ & 0,832 & 0,562 & 0,426 & 0,230 & Yes & Yes \\
\hline
\end{tabular}

\section{5-2. Structural model}

The estimated structural model shows an acceptable fit quality. Chisquared value $=243.905$, degree of freedom $=71, \mathrm{CMIC} / \mathrm{DF}=3.435$ less than 5 recommended by Hair et al. (2010). GFI=0.911 and CFI=0.926 bove 0.9 recommended by Hair et al. (2010) and Kline,(2011). RMSEA=0.088 which less than 0.1 indicated Akrout, 
(2010); Kline, (2011).

The validation of the structure of structural model allowed us to test the research hypotheses. Table 2 shows the hypothesis test results. Hypothesis 1: "ethical climate has a positive and direct effect on Organizational Citizenship Behaviors (OCB)" is accepted since $\beta=0,148, \mathrm{p}<0.001, \mathrm{CR}=2.894>1,96$.

Also, hypothesis 2 according to which the ethical climate has a positive and significative effect on Organizational trust is accepted $(\beta=0,240, p<0.001, C R=2.440>1,96)$. Hypothesis 3 indicating Organizational trust has a positive and significative effect on Organizational Citizenship Behaviors (OCB) is accepted ( $\beta=0,339$, $\mathrm{p}<0.001, \mathrm{CR}=7.625>1,96)$. Perhaps, Hypothesis 4: Ethical Climate has a positive and significant effect on OCB through Organizational trust is rejected because $\beta=0,061, \mathrm{p}<0.001, \mathrm{CR}=1.443<1,96$. (See table 2).

Table 2: The results of the structural model

\begin{tabular}{|c|l|c|c|c|}
\hline \multicolumn{2}{|c|}{ Hypothesis } & Coefficient & $\begin{array}{c}\text { Critical Ratio } \\
\text { CR }\end{array}$ & Hypothesis validation \\
\hline H 1 & Ethical Climate ---> OCB & $0,148^{* * *}$ & 2.894 & hypothesis accepted \\
\hline H2 & Ethical Climate ---> Organizational trust & $0,240^{* *}$ & 2,440 & hypothesis accepted \\
\hline H3 & Organizational trust ---> OCB & $0,339^{* * *}$ & 7,625 & hypothesis accepted \\
\hline H4 & Ethical Climate--- $\rightarrow$ Organizational trust ---> OCB & 0.061 & 1.443 & $\begin{array}{c}\text { Hypothesis } \\
\text { rejected }\end{array}$ \\
\hline
\end{tabular}

$* * \mathbf{p}<\mathbf{0 . 0 5}, * * * \mathbf{p}<\mathbf{0 . 0 0 1}$.

\section{5-3. Test of mediation}

In order to test hypothesis 5 relating to the mediation of organizational trust, reference was made to Baron and Kenny (1986) four steps. In our study, the ethical climate is the independent variable, OCB is the dependent variable while organizational trust is the mediating variable. Step 1 of the Baron and Kenny (1986) is verified since Hypothesis "ethical climate has a positive and direct effect on Organizational Citizenship Behaviors (OCB)" is accepted. Step 2 is also checked because hypothesis 2 "the ethical climate has a positive and significative effect on Organizational trust" is accepted. Similarly, for step 3, which hypothesis 3 "Organizational trust has a positive and significative effect on Organizational Citizenship Behaviors (OCB)" is accepted. However, after the introduction of the organizational trust variable, the relationship between the ethical climate and OCB is no longer significant which can be explained by the complete mediation of organizational trust (Baron and Kenny ,1986).

\section{6- Discussion}

In this paper we tried to study the effects of the ethical climate on OCBs through organizational trust. Our study highlights the positive and direct impact of the ethical climate to Organizational Citizenship Behaviors at the organizational level (hypothesis 1). This implies that the existence of ethical climate in the telecommunication activities promotes the development of Organizational Citizenship Behaviors of employees who have positive effects on the organization. Empirical research in the literature support this result (Ruiz-Palomino \& MartinezCanas ,2014, Çavuş and Develi, 2015). In fact, Huang et al. (2013) have established a study among nurses on the links between ethical climate and OCB. They found that hospitals can increase nursing OCB by influencing organizational ethical climate, job satisfaction and organizational commitment. More specifically, by distinguishing between five types of ethical climate (care climate, independent climate, environment and law codes, rules climate and instrumental climate), the authors suggested that care climate and rules climate positively influence OCB at the hospital.

The relationship between ethical climate and OCB is generally treated without presentation of the process by which ethical climate affects OCB. Our paper fills this gap by identifying a mediation mechanism through organizational trust. In our study, ethical climate has been shown to positively influence organizational trust (Hypothesis 2), demonstrating that the ethical climate is an important antecedent for generating trust between members of an organization. This result supports conclusions of Pučètaitė and Lämsä (2008), Lilly et al. (2016 ) and Ensari M.S (2016). Also, hypothesis 3 stating that organizational trust positively influences OCBs has been confirmed. This result supports those of Dirks and Ferrin (2002), Ong, (2013) and Singh and Srivastava, (2009). In the long run, organizations that develop trusting relationships with their employees encourage them to interact reciprocally by adopting OCBs that have a positive impact on the organization. (Singh and Srivastava, 2016)

the rejection of hypothesis 4 and the acceptance of hypothesis 5 confirms the complete mediation of organizational trust in the relationship between ethical climate and OCB. These results can be explained by the fact that trust plays a complex role in organization ( Shahid et al. 2018). The success or failure of any organization is directly and positively related to the level of existence of organizational trust within it; as well as the extent to which it is appropriately handled by the daily managerial practices (Huff et al. 2003).

\section{7- Conclusion and Managerial Implications}

We studied, in this paper, the effects of ethical climate on OCB through the mediation of organizational trust. The 
empirical validation of our research has several managerial implications. Firstly, our study brings to human resources managers new knowledge to optimize and improve the employees OCB through the implementation of ethical climate within the company. Ethics has positive effects on behavior and attitudes of employees (Pagliaro et al. 2018) and improve their employees contextual performance including OCBs (Coleman et Borman ,2000, Motowidlo et al. 2000). Secondly, research on OCB have granted limited importance to developing mechanisms for these behaviors especially in organizations that wish to use OCB to provide better quality of service (Wolfe Morrison, 1996). In this context, our research provides new knowledge to the field of OCB. It highlights the methods and tools to promote employee OCB in Moroccan telecommunication activities. Thirdly, the complete mediation of organizational trust in our model tells managers that employee attitudes and behaviors can be managed through the creation of trusted relationships between employees and the organization as well as between employees themselves.

Future research should test the model with larger samples and other contexts or sectors. We propose also to explore the moderating role of organizational justice, seniority, flexibility, competence, cooperation,.. in the relationship ethical climate and OCBs.

\section{References}

Akrout F. (2010). Les Méthodes d'équations Structurelles (1ére Edition) Sfax

Arnaud A. and Schminke T. (2012). The Ethical Climate and Context of Organizations, Organization Science in Advance. 1-14.

Baron R. M. and Kenny D. A. (1986). The Moderator-Mediator Variable Distinction in Social Psychological Research: Conceptual, Strategic, and Statistical Considerations. Journal of Personality and Social Psychology 51, 6, 1173-1182

Bateman T.S, Organ D.W,(1983). Job Satisfaction and the Good Soldier: The Relationship Between Affect and Employee "Citizenship". The Academy of Management Journal ·26, 4, 587-595.

Borman W. C., Motowidlo S. J. (1993). Expanding the criterion domain to include elements of contextual performance. In Schmitt N. \& Borman W. C. (Eds.), Personnel selection in organizations (p. 71-98), San Francisco: Jossey-Bass.

Çavuş M.F.and Develi A. (2017), Ethical Climate and Organizational Citizenship Behavior, International Journal of Human Resource Studies 7. 1, 38-51.

Coleman, V. I., \& Borman, W. C. (2000). Investigating the underlying structure of the citizenship performance domain. Human Resource Management Review, 10, 25-44. doi:10.1016/S1053-4822(99)00037-6

Dalal R. S., Lam H., Weiss H. M., Welch E. R. Hulin C. L. (2009). A within-person approach to work behavior and performance: concurrent and lagged citizenship- counterproductivity associations, and dynamic relationships with affect and overall job performance. Academy of Management Journal, 52,5.

Deshpande, S. P., Joseph, J. and Shu, X. 2011. Ethical Climate and Managerial Success in China. Journal of Business Ethics, 527-534

Dirks, K. T., \& Ferrin, D. L. (2002). Trust in Leadership: Meta-Analytic Findings and Implications for Research and Practice. Journal of Applied Psychology, 87(4), 611-628.

Ensari M.S (2016) the mediating effect of perceived ethical climate on organizational commitment, trust and turnover intention interactions: a research on insurance sector, European law review, 58, 5

Farh, J. L., Earley, P. C., \& Lin, S. C. (1997). Impetus for action: A cultural analysis of justice and organizational citizenship behavior in Chinese society. Administrative Science Quarterly, 42, 421-444.

Farzianpour F., Foroushani A. R., Kamjoo H. and Hosseini S.S. (2011) Organizational Citizenship Behavior (OCB) among the Managers of Teaching Hospitals. American Journal of Economics and Business Administration 3 , 534-542

Fornell, C., \& Larcker, D. F. (1981). Evaluating structural equation models with unobservable variables and measurement error. Journal of Marketing Research, 18(1), 39-50.

Graham, J. W. (1989). Organizational citizenship behavior: Construct redefinition, operationalization, and validation. Unpublished working paper, Loyola University of Chicago.

Grobler A. (2015) An adapted measure of ethical climate in organisations - a South African study

Hair, J., Black, W., Babin, B., Anderson, R., \& Tatham, R. (2010). Multivariate data analysis. New york: Pearson Prentice Hall. p: 752

Harper, P.J.(2015), Exploring forms of organizational citizenship behaviors (OCB): antecedents and outcomes, Journal of Management and Marketing Research. 18.

Huang, C., You, C. and Tsai, M. 2012. A multidimensional analysis of ethical climate, job satisfaction, organizational commitment, and organizational citizenship behaviours. Nursing Ethics, 19(4): 513-529.

Huff, L., \& Kelley, L. (2003). Levels of Organizational Trust in Individualist Versus Collectivist Societies: A Seven Nation Study. Organizational Science, 14(1), 81-90

Hwang, J. and Park, H. 2014. Nurses ${ }^{e e}$ perception of ethical climate, medical error experience and intent-to-leave. 
Nursing Ethics, 21(1): 28-42.

Johnson S. K., Holladay C. L., Quinones M. A. (2009). Organizational Citizenship Behavior in Performance Evaluations: Distributive Justice or Injustice? Journal of Bussines Psychology, 24.

Jose A, Thibodeaux M.S., (1999), Institutionalization of Ethics: The Perspective of Managers .Journal of Business Ethics. 22(2):133-143

Khlif W. , (2000). Processus de construction de la confiance et configuration de contrôle de gestion, Revue Tunisienne des Sciences de Gestion, 7.

Kline, R. B. (2011). Methodology in the Social Sciences. Principles and practice of structural equation modeling (3rd ed.). Guilford Press.

Lee S.H. and Ha-Brookshire (2018), The effect of ethical climate and employees' organizational citizenship behavior on U.S. fashion retail organizations' sustainability performance, Corporate Social Responsibility and Environment Management, 25, 5.

Lee, K., \& Allen, N.J. (2002). Organizational citizenship behavior and workplace deviance: The role of affect and cognitions. Journal of Applied Psychology, 87, 131-142

Lilly J., Duffy J.A., Wipawayangkool K., (2016), The Impact of Ethical Climate on Organizational Trust and the Role of Business Performance: If Business Performance Increases, Does Ethical Climate Still Matter? Journal of Behavioral and Applied Management, 17, 1, 2016

Lovelock C., Wirtz J., Lapert D., Munos A. (2008) marketing des services, 6 éme edtition , edirion: pearson, USA.

Martin K. D., Cullen J. B. (2006). Continuities and Extensions of Ethical Climate Theory: A Meta-Analytic Review. Journal of Business Ethics 69,175-194

Mayer, D.M., Kuenzi, M., and Greenbaum, R.L. 2010. Examining the link between ethical leadership and employee misconduct: the mediating role of ethical climate. Journal of Business Ethics, 95: 7-16.

Mohammad J., Quoquab Habib F. Zakaria S. ( 2010).organizational citizenship behavior and commitment: do age and tenure make any difference?, $B M Q R, 11$, No.3

Motowidlo, S.J. (2000). Some basic issues related to contextual performance and organizational Citizenship behavior in human resource management. Human Resource Management Review, 10,1.

Newman A, Round H., Bhattacharya S., Roy A (2017), Ethical Climates in Organizations: A Review and Research Agenda ,Business Ethics Quarterly,27:4 , 475-512

Ong,L.D. (2013)Workplace friendship, trust in coworkers and employees' OCB, Actual Problems of Economics $140,2,289-294$

Organ, D. W. (1988). Organizational citizenship behavior: The good soldier syndrome. USA: D.C. Heath and Company

Organ, D.W., P.M. Podsakoff and S.P. MacKenzie 2006. Organizational Citizenship Behavior: Its Nature, Antecedents and Consequences. 1st Edn., Sage Publications, Thousand Oaks, Calif.

Pagliaro S, Lo presti A, Barattucci M, Giannella VA and Barreto M(2018) On the Effects of Ethical Climate(s) on Employees’ Behavior: A Social Identity Approach. Frontiers in Psychology 9:960.

Pariente G., Pesqueux Y.,\& Simon E., (2010). Les dérives éthiques dans l'entreprise. Mangement \& avenir, 33.

Podsakoff, P.M., Mackenzie, S.B., Paine, J.B., et al. (2000) Organizational Citizenship Behaviors: A Critical Review of the Theoretical and Empirical Literature and Suggestions for Future Research. Journal of Management, 26, 513-563.

Pučètaitè, R., \& Lämsä, A. M. (2008a). Advancing organizational trust in a post-socialist context: role of ethics management tools. Economics and Management, 13, 381-388.

Pučètaitè, R., \& Lämsä, A. M. (2008b). Developing Organizational Trust Through Advancement of Employees' Work Ethic in a Post-Socialist Context. Journal of Business Ethics, 82(2), 325-337.

r?Rich R.L., Lepine J. A., Crawford E.R. (2010). Job engagement: antecedents and effects on job performance. Academy of Management Journal, 53,3.

Robinson S. L., Rousseau D. M. (1994). Violating the psychological contract: not the exception hut the norm. Journal of Organizational Behavior, 15.

Rubin R.S , BommerW.H., Bachrach D.G. (2010),Operant leadership and employee citizenship: A question of trust? The Leadership Quarterly 21,3,400-408

Ruiz-Palomino P. \& Martínez-Cañas R. (2014) Ethical Culture, Ethical Intent, and Organizational Citizenship Behavior: The Moderating and Mediating Role of Person-Organization Fit. Journal of Business Ethics 120 (1):95-108.

Schneider, B. (1975). Organizational climate: an essay. Personnel Psychology, 28, 447-479.

Schwartz, M. S. (2001). The nature of the relationship between corporate codes of ethics and behaviour. Journal of Business Ethics, 32, 247-262.

Schwepker, C.H., Ferrell O.C., and Ingram T. N. (1997). The Influence of Ethical Climate and Ethical Conflict on Role Stress in the Sales Force. Journal of the Academy of Marketing Science, 25.

Shahid S., Zain Z. Alam S.S. (2018) The Mediating Effect of Organizational Trust on Human Resource 
Management and Affective Commitment, International Journal of Human Resource Studies, 8, 1, 38-59.

Shin Y. (2012 ) CEO Ethical Leadership, Ethical Climate, Climate Strength, and Collective Organizational Citizenship Behavior, Journal of Business Ethics, 108, 3, 299-312.

Singh, U., Srivastava, K.B.L. (2009). Interpersonal trust and organizational citizenship behaviour. Psychological Studies, 54, 65-76.e

Singh, U., Srivastava, K.B.L. (2016).Organizational Trust and Organizational Citizenship Behaviour, Global Business Review, 17,3.

Singhapakdi, A. \& Vitell, S. J. (2007). Institutionalization of Ethics and Its Consequences: A Survey of Marketing Professionals. Journal of the Academy of Marketing Science, 35 ,2, 284-294.

Stevens B.(2008). Corporate Ethical Codes: Effective Instruments For Influencing Behavior, Journal of Business Ethics, 78 .

Uhl-Bien, M., Graen, G. B., \& Scandura, T. A. (2000). Implications of leader-member exchange (LMX) for strategic human resource management systems: Relationships as social capital for competitive advantage. In G. Ferris (Ed.), Research in personnel and human resource management ,18,137-185.

Van Dyne L, Cummings LL, and McLean Parks J (1995) Extra-role behaviors: In pursuit of construct and definitional clarity. In: Cummings LL, Staw BM (eds) Research in Organizational Behavior, 17. Greenwich, 215-285.

Victor, B., \& Cullen, J.B. (1988) The organizational bases of ethical work climates. . Administrative Science Quarterly, 33, 101-125

Victor, B., \& Cullen, J.B.. (1987) A theory and measure of ethical climates in organizations. Research in Corporate Social Performance and Policy, 9, 51-71.

Wat, D., \& Shaffer, M. (2005). Equity and relationship quality influences on organizational citizenship behaviors. Personnel Review, 34(4), 406-512.

Whitener E., Brodt S., Korsgaard A. et Werner J. (1998). Managers as Initiators of Trust: An Exchange Relationship Framework for Understanding Managerial Trustworthy Behavior. Academy of Management Review, 23 (3).

Williams L.J. and Anderson S.E. (1991). Job satisfaction and organizational commitment as predictors of organizational citizenship and in-role behaviors. Journal of Management 17(3).

Wolfe Morrison E. (1996) Organizational Citizenship Behavior as a Critical Link between HRM Practices and Service Quality, Human Resource Management, $35,4$.

You C.S, Huang C.C, Wang H.B., Liu K.N., Lin C.H., Tseng J.S., (2013). The relationship between corporate social responsibility, job satisfaction and organizational commitment. The International Journal of Organizational Innovation, 5,4 . 